\title{
Microbial insecticides in forestry
}

\author{
by J.C. Cunningham and K. van Frankenhuyzen
}

\begin{abstract}
Research has been conducted in Canada on bacteria, viruses, protozoa, fungi and nematodes for control of forest insect pests. Environmental concerns regarding the use of synthetic chemical pesticides have resulted in increased use of the only microbial control agent that is commercially available, the bacterium Bacillus thuringiensis (B.t.). There are currently 18 B.t. products registered for forestry use in Canada. The greatest use of B.t. has been for control of spruce budworm, Choristoneura fumiferana, although it has been extensively used on several other species of defoliating lepidopterous pests.

The use of other microbial control agents is insignificant compared to B.t. Three viral insecticides containing baculoviruses are registered in Canada, two for control of Douglasfir tussock moth and one for control of redheaded pine sawfly. Registration petitions have been submitted for viral insecticides to control European pine sawfly and gypsy moth.

The advent of recombinant DNA technology has opened the door to limitless possibilities for the genetic manipulation of microbial insecticides. Genetic engineering of B.t. toxin genes into other microorganisms and into plants has been accomplished. Foreign genes have been expressed in baculoviruses; most of these products have pharmaceutical applications unrelated to insect control, but this technology can be used to engineer viral insecticides for enhanced activity.
\end{abstract}

\section{Résumé}

Des recherches ont été entreprises au Canada sur les bactéries, les virus, les protozoaires, les champignons et les nématodes qui pourraient contrôler les insectes forestiers ravageurs. Des considérations environnementales touchant l'utilisation de pesticides chimiques de synthèse ont mené à une utilisation accrue du seul agent de contrôle microbien commercialement disponsible, la bacille Bacillus thuringiensis (B.t.). Il existe actuellement 18 produits à base de B.t. homologués à des fins d'utilisation forestière au Canada. La plus grande utilisation du B.t. a été retenue pour le contrôle de la tordeuse des bourgéons de l'épinette, Choristoneura fumiferana, même s'il a été utilisé extensivement contre quelques autres espèces de lépidoptères qui détruisent le feuillage.

L'utilisation des autres agents de contrôle microbien est insignifiante comparativement au B.t. Trois insecticides viraux contenant des baculovirus sont homologués au Canada, deux pour le contrôle de la chenille à houppes du douglas et un pour le contrôle du diprion de LeConte. Des demandes d'homologation ont été déposées pour des insecticides viraux pour lutter contre le diprion du pin sylvestre et la spongieuse.

Les développements rencontrés en technologie de recombinaison de l'ADN ont ouverts les portes sur des possibilités illimitées de manipulation génétique des insecticides microbiens. Le génié génétique des gènes de toxines dans les autres micro-organismes et les plantes est maintenant atteint. Les gènes étrangers sont désignés en terme de baculovirus; la plupart de ces produits ont des applications pharmaceutiques non reliées au contrôle des insectes, mais cette technologie peut être utilisée pour concevoir des insecticides viraux qui connaîtront une activité accrue.

\section{Introduction}

Canada has always been a world leader in the development and use of microbial insecticides to combat forest insect pests. Forests are Canada's most important natural resource and trees that support this industry suffer the ravages of several major insect pests. The forest ecosystem is stable compared to the turbulence often encountered in agriculture and this makes forests more conducive to the use of biological control agents that tend to be slower acting than synthetic chemical insecticides. Although several forest managers would argue, some damage to forest trees can generally be tolerated, provided trees are not killed or deformed. Defoliation of forest trees for a few years, with concomitant loss of growth increment, may be acceptable, whereas insect damage to agricultural crops is generally not tolerated in developed countries by either farmers or consumers.

Research on microbial control of forest insect pests intensified in Canada in the 1940s when it was discovered that the European spruce sawfly, Gilpinia hercyniae, was controlled by a nuclear polyhedrosis virus (NPV), probably accidentally introduced with parasites imported from Europe in the late 1930s (McGugan and Coppel 1962). Fifty years later, European spruce sawfly is still at an endemic level,

Forestry Canada, Forest Pest Management Institute, P.O. Box 490, Sault Ste Marie, Ontario P6A 5M7. held in check by the NPV and parasites. Canadian forestry officials were so impressed with the demise of the European spruce sawfly, that the same remedy was attempted to control another major insect pest, spruce budworm, Choristoneura fumiferana. The Laboratory of Insect Pathology opened in Sault Ste. Marie, Ontario in 1950. After amalgamation with the Chemical Control Research Institute in 1976, this research centre was renamed the Forest Pest Management Institute. The main research thrust of the Laboratory of Insect Pathology was the development of viruses for control of forest insect pests, although bacteria, protozoa, and fungi were also studied as potential biocontrol agents. Viruses were imported from the European fir budworm, Choristoneura murinana, but the spruce budworm was not as amenable to control with viruses as was the European spruce sawfly. A virus for spruce budworm control has yet to be developed after years of intensive research. The spruce budworm continues to rank as Canada's most economically destructive forest insect pest. Genetic manipulation of one of the several viruses which infect it may yield a solution.

The Forest Pest Management Institute has played a major role in the successful use of microbial agents to control several forest insect pests. A highly effective virus was found for control of European pine sawfly, Neodiprion sertifer (Bird 1953) and this virus has been used in 12 countries (Cunningham and Entwistle 1981). Pioneering work on the 
bacterium, Bacillus thuringiensis (B.t.) in Sault Ste. Marie demonstrated its potential for controlling lepidopterous insect pests (Heimpel and Angus 1959; Angus 1964). B.t. is now an operational alternative to synthetic chemical insecticides for control of spruce budworm (Smirnoff and Morris 1982) and several other major forest defoliators (van Frankenhuyzen 1990).

In the last decade, there has been growing public concern about the environmental effects of broad-spectrum synthetic chemical insecticides, which has led to increased use of highly specific, environmentally more benign microbial agents. B.t. is the only microbial agent registered and commercially available in Canada and it clearly dominates the field. Presently, the use of other agents such as viruses, is insignificant compared to the use of B.t. Also, the advent of recombinant DNA technology is having a major impact on the development of microbial insecticides. It is now theoretically possible to engineer a microorganism to control some pests in particular habitats. Several products resulting from genetic manipulation of B.t. are already available, and more are being developed. Likewise, there is considerable interest in engineering entomopathogenic viruses with a view to making them more effective insecticides. Protozoa, fungi and nematodes are also considered microbial agents, but their use in forestry in Canada has been restricted to small, experimental ground sprays.

\section{Microbial Agents}

Bacillus thuringiensis. A wide range of bacteria has been isolated from insect pests, but only B.t. has been developed as a microbial insecticide for forest insect pests. Three subspecies of B.t. are used in commercial products. B.t. subspecies kurstaki is active against lepidopterous pests and is used in all commercial products applied on Canadian forests. B.t. subspecies israelensis is used against Diptera, particularly for control of aquatic larvae of blackflies and mosquitoes. B.t. subspecies tenebrionis is effective against some species of Coleoptera and has been used mainly on Colorado potato beetle, Leptinotarsa decemlineata. Subspecies israelensis and tenebrionis have not been used on forest insect pests, but they may have practical applications for control of some maggots and beetles.

The bacterium B.t. is rod-shaped, Gram-positive, crystalliferous and spore-forming. When cultured under appropriate conditions, it sporulates and forms a crystalline parasporal body containing delta-endotoxins. When sporulation is complete, the bacterial cell wall disintegrates and releases spores and crystals into the surrounding medium. When ingested by susceptible insect larvae, the crystal, which is composed of large molecules of protoxin, is solubilized by alkaline gut juices and broken down by gut proteases releasing smaller, potent deltaendotoxins. These activated toxins severely damage gut cells. This is followed by spore germination and septicemia which kills the insects (Heimpel and Angus 1959). Feeding stops immediately because of the toxin, although spruce budworm larvae can recover from lower dosages that only cause feeding inhibition (Fast and Régnière 1984; van Frankenhuyzen and Nystrom 1987). Although B.t. is common in soil microbiota (DeLucca et al. 1981; Martin and Travers 1989), it has never been observed to control forest insect pest populations in nature and must be applied as an insecticidal spray.

B.t. is produced in liquid culture using an inexpensive protein source such as soy meal. There are currently 18 B.t. products registered for forestry use in Canada by 8 different companies (van Frankenhuyzen 1990). Of these, 11 products are readily available and the remaining 7 have been replaced by improved formulations without cancellation of their registrations. A further two B.t. products have registrations pending.

Baculoviruses. Unlike B.t., viruses only grow in living cells and it is necessary to propagate them either in insect host larvae or in insect cell cultures. Presently, propagation in host larvae (in vivo) is the only practical method of large scale production, although research on production in cell cultures (in vitro) is also being conducted. Nine different groups of viruses are known to infect insects (Entwistle and Evans 1985), but only type A and type B baculoviruses, namely nuclear polyhedrosis viruses (NPV) and granulosis viruses (GV), have been used extensively to control forest insect pests in Canada. Limited trials have been conducted with cytoplasmic polyhedrosis viruses (CPV) and an entomopoxvirus (EPV).

Baculoviruses have rod-shaped virus particles and their nucleic acid is circular, double-stranded DNA. NPVs and GVs have virus particles contained within inclusion bodies; there are many particles in NPV inclusion bodies and one, or rarely two, in GV inclusion bodies. These inclusion bodies protect the virus particles. It is also possible to observe these inclusion bodies through a light microscope making diagnosis and dosage standardization relatively simple. Baculoviruses have been isolated mainly from Lepidoptera and Hymenoptera, but a few have been reported from Diptera, Coleoptera, Neuroptera, Trichoptera and Crustacea. Baculoviruses are highly host-specific and many are known to infect only one species. The baculovirus with the widest known host range is that of the alfalfa looper, Autographa californica, which has been reported to infect 43 species of Lepidoptera from 11 different families (Payne 1986).

Like B.t., baculoviruses have to be ingested to cause infection. The inclusion body protein dissolves in the alkaline larval gut juice and virus particles are released. These virus particles infect gut cells in susceptible species and then usually spread to other organs. In the final stages of infection, more inclusion bodies are produced in infected cells. When larvae die, massive quantities of inclusion bodies are released into the environment. These may infect more larvae (horizontal transmission) or the next generation of larvae (vertical transmission). Baculoviruses are generally slow acting and some feeding damage can occur between ingestion of a lethal dose and death of the insect larva.

Protozoa. Protozoa of the phylum Microspora are prevalent in populations of many forest insect pests. They are chronic rather than acute pathogens and some are transovarially transmitted. They retard larval and pupal development, fecundity and longevity of adult moths. They must be ingested to cause infection and are obligate parasites. They have to be produced in susceptible insect larvae for field trials and cannot be grown economically in culture. Small scale field trials have been conducted in Canada with Nosema fumiferanae and Pleistophora shubergi against spruce budworm and with $N$. disstriae against forest tent caterpillar, Malacosoma disstria (Wilson 1982). Nosema locustae has been registered in the USA for grasshopper control, but there are no plans for developing protozoa as microbial insecticides for forest insect pests in Canada. 
Fungi. Spectacular epizootics of fungi of the order Entomophthorales have been observed to decimate populations of hemlock looper, Lambdina fiscellaria, in Newfoundland (Otvos et al. 1973), and spruce budworm in both Ontario and Newfoundland (Harvey and Burke 1974; Otvos and Moody 1978). However, there are problems in the mass production of either conidia or resting spores of such fungi in culture. Entomophthorales could possibly be used to initiate and maintain epizootics, whereas other fungi such as imperfect fungi, which can be easily grown in liquid culture, could be applied as biological insecticides in much the same manner as B.t. Fungi infect insects by penetrating the cuticle and invading the haemocoele. They are slow to kill their host. A few species of fungi are registered as mycoinsecticides around the world and used on agricultural crops. Several small scale, ground spray trials have been conducted in Canada on spruce budworm and forest tent caterpillar, but no mycoinsecticides are registered in Canada and there are no plans to develop mycoinsecticides for forestry use.

Nematodes. Steinernematid nematodes can be economically mass-produced on a variety of substrates and are available commercially from several sources in the USA. These nematodes attack a wide range of insect species. They are attracted to insects by a carbon dioxide gradient and actively seek out the target, entering the insect by the mouth, anus or spiracles. A bacterium Xenorhabdus nematophilus, is associated with these nematodes. The bacteria kill larvae quickly and the nematodes feed and multiply in the putrefying cadavers.

Recently, ground spray trials have been conducted on spruce budmoth, Zeiraphera canadensis, with the Steinernematid nematode, Steinernema carpocapsae, formulated in a carrier used for a B.t. product. Encouraging results have been obtained with the same nematode for control of the debarking weevil, Hylobius congener. Soil plugs were soaked in a suspension containing nematodes before seedlings were planted (D.E. Eidt and S. Zervos, pers. comm.). Experimental sprays were conducted with $S$. carpocapsae against black army cutworm, Actebia fennica, in Newfoundland in 1990 (R. West, pers. comm.).

Bacteria, viruses, fungi and protozoa are regulated under the Pest Control Products Act. Nematodes imported into Canada are covered by the Plant Quarantine Act that is also used to regulate importations of parasites and predators. There is no legislation regarding indigenous nematodes produced in Canada. Expensive safety testing required for other microbial agents is not required for nematodes; thus interest in them has increased. Desiccation of sprayed nematodes has been a major problem in the past, but this may be solved with the use of a spray formulation developed for B.t.

\section{Use of B.t. in Canadian Forests}

The first aerial spray trials with B.t. in Canada, in 1960, were against western black-headed budworm, Acleris gloverana, in British Columbia (Kinghorn et al. 1961) and spruce budworm in New Brunswick (Mott et al. 1961). Most of the early research on B.t. was conducted on spruce budworm in the 1970s and efforts intensified when a collaborative agreement was signed in 1977 between the Canadian Forestry Service and the USDA Forest Service to accelerate

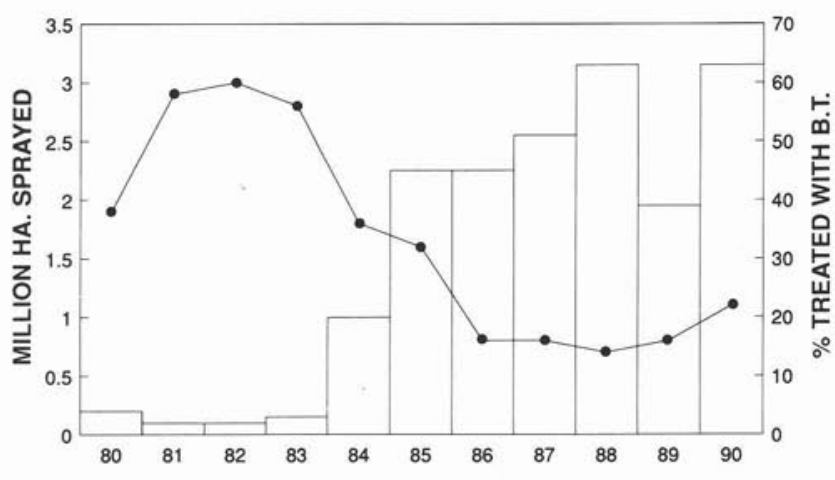

Figure 1. Total area aerially sprayed annually in Canada to control spruce budworm between 1980 and 1990 (line) and the percent of area treated with Bacillus thuringiensis (bars).

research on both the spruce budworm and western spruce budworm, Choristoneura occidentalis. This 5-year program, named CANUSA, involved all aspects of budworm research. Progress in the development of B.t. as an operational alternative to synthetic chemical pesticides has been reviewed by Cunningham (1985a) and van Frankenhuyzen (1990). In 1978, the recommended dosage for B.t. for spruce budworm control was 20 Billion International Units (BIU) in $4.7 \mathrm{~L} / \mathrm{ha}$. By 1990 , the dosage had increased to $30 \mathrm{BIU} / \mathrm{ha}$ and emitted volumes reduced to as low as $1.6 \mathrm{~L} / \mathrm{ha}$. These changes were made possibly by the availability of higher potency formulations that can be applied without dilution. It was established that one $50 \mu \mathrm{m}$ droplet of a $12.7 \mathrm{BIU} / \mathrm{L}$ product per balsam fir needle will give effective spruce budworm control with an efficacious dose of toxin in each droplet (Fast et al. 1986; Lambert 1987). B.t. products containing more BIUs per litre, applied at lower volumes, have the added benefits of reducing transportation costs and increasing spray plane productivity. When applied undiluted, mixing errors are eliminated.

Between 1980 and 1984, only 2 to $4 \%$ of the total area sprayed for spruce budworm was treated with B.t. (Fig. 1). The remainder was treated with the chemical insecticides fenitrothion and aminocarb. The use of B.t. increased to $63 \%$ in 1990. By far the greatest use of B.t. in Canada is for spruce budworm control with 2.8 million ha treated with B.t. in eastern Canada between 1985 and 1990. All B.t. products registered for forestry use in Canada have spruce budworm on the label, but it is necessary to check labels to determine if other forest insect defoliators are included. Between 1985 and 1990, 204,000 ha were treated with B.t. in Ontario to control gypsy moth, Lymantria dispar, 841,000 ha in Ontario to control jack pine budworm, C. pinus, and 51,000 ha in Newfoundland to control hemlock looper.

Bidding for forestry contracts is highly competitive and the cost of B.t. has been fairly constant at between 35 and $40 \mathrm{c}$ per BIU from 1986 to 1990 . Synthetic chemical insecticides cost less than B.t. but this differential has been steadily decreasing. In Quebec, B.t. for spruce budworm was 4.5 times more expensive than chemical insecticides in 1981 and only 1.7 times in 1985 . Chemical insecticide sprays were discontinued in Quebec in 1985. New Brunswick is the only province still using fenitrothion (aminocarb is no longer available) for spruce budworm control and here B.t. was 1.2 times more expensive in 1988. Because New Brunswick sprays large areas relative to other provinces, their use of 
fenitrothion has a marked effect on the statistics for B.t. use in eastern Canada.

The use of B.t. is not without problems. It has a narrower window for spray applications than chemical pesticides, it is not as effective as chemical pesticides at high insect population densities, and it is more susceptible to post-spray weathering of the deposit. These factors constrain the use of B.t. and cause a higher incidence of unacceptable defoliation following the application of B.t. than the application of chemical insecticides.

B.t. subspecies kurstaki affects only larval stages of Lepidoptera, whereas broad-spectrum synthetic chemical insecticides have an impact on a wide range of arthropods in the forest ecosystem, including beneficial parasites, predators and pollinators. However, some criticism has been leveled at B.t. because of its potential impact on non-target beneficial or desirable Lepidoptera. These species may be important in food chains, they may be aesthetically attractive, or they may be endangered species.

\section{Genetic Manipulation of B.t.}

There is considerable commercial interest in conventional B.t. products, genetically modified B.t. products, and development of transgenic plants that can express the B.t. toxin gene. Prior to 1980, B.t. products were manufactured by Abbott, Biochem and Sandoz. Currently, many more companies are involved in manufacturing conventional B.t. spray products while there is also a shift in research and development towards genetic manipulation, strain improvement and the development of novel delivery techniques, such as transgenic plants (Table 1).

B.t. toxin genes are located on plasmids and can be relatively easily isolated, cloned and sequenced; about 50 toxin genes have now been sequenced. There are basically three approaches to genetic engineering of B.t. Firstly, B.t. can be manipulated by adding more toxin genes or modifying existing toxin genes. Secondly, the B.t. toxin gene can be engineered into another microorganism that is prevalent in the habitat of the target insect pest and ingested while larvae are feeding. Alternatively, it can be engineered into a bacterium which does not disintegrate when it sporulates, thus protecting the toxin from weathering. Thirdly, the B.t. toxin gene can be engineered into the host plant of the target insect species and the toxin produced in the foliage.

When modifying the toxin in B.t., it may be possible to tailor specificity and increase toxicity. Ecogen Inc. used a naturally occurring plasmid transfer mechanism, conjugation, to combine toxin genes from two strains into one B.t., resulting in a product called Condor for forest pests. Strains of B.t. which contain both the lepidopterous and coleopterous active toxins have been developed for use against a wider range of crop pests, such as those found on potatoes (Carlton et al. 1990). Persistence has been increased for a Mycogen Corporation product called MVP ${ }^{\mathrm{TM}}$ Bioinsecticide where a B.t. gene is expressed in Pseudomonas fluorescens, which does not lyse at the end of its fermentation cycle. The Pseudomonas is then killed and cross-linking of the cell wall enhances persistence of the B.t. toxin on leaf surfaces (Gelernter 1990).

The transfer of toxin genes could have applications in forestry. The toxin gene may be put into another microorganism that is found in the same habitat as the pest species, allowing
Table 1. Companies and their involvement in Bacillus thuringiensis products for insect control

\begin{tabular}{clccc}
\hline Year & Company & $\begin{array}{c}\text { Conventional } \\
\text { spray } \\
\text { products }\end{array}$ & $\begin{array}{c}\text { Genetic } \\
\text { manipulation } \\
\text { and strain } \\
\text { improvement }\end{array}$ & $\begin{array}{c}\text { Toxin } \\
\text { gene } \\
\text { engineered } \\
\text { into plants }\end{array}$ \\
\hline$<1980$ & Abbott & $\mathrm{X}$ & & \\
& Biochem & $\mathrm{X}$ & & \\
& Sandoz & $\mathrm{X}$ & & \\
$>1980$ & Solvay & $\mathrm{X}$ & & \\
& Novo & $\mathrm{X}$ & & $\mathrm{X}$ \\
& Ciba Geigy & $\mathrm{X}$ & & $\mathrm{X}$ \\
& Zoecon & $\mathrm{X}$ & $\mathrm{X}$ & \\
& ICI & $\mathrm{X}$ & $\mathrm{X}$ & $\mathrm{X}$ \\
& Sumitomo & $\mathrm{X}$ & $\mathrm{X}$ & $\mathrm{X}$ \\
& Ecogen & $\mathrm{X}$ & $\mathrm{X}$ & $\mathrm{X}$ \\
& Mycogen & $\mathrm{X}$ & & $\mathrm{X}$ \\
Monsanto & & & $\mathrm{X}$ \\
Rohm \& & & & $\mathrm{X}$ \\
& Haas & & & \\
& Plant Genetic & & & \\
Systems & & & \\
Agracetus & & & \\
Calgene & & & \\
Sungene & & & & \\
\hline
\end{tabular}

it to be ingested along with food. A B.t. subspecies israelensis toxin gene was engineered into a Bradyrhizobium sp. that forms nitrogen-fixing nodules on pigeon peas, Cajanus cajan, to protect them from root nodule damage by larvae of the dipterous insect, Rivellia angulata (Nambiar et al. 1990). B.t. toxin genes can be used to enhance other pathogens, and there are examples of this gene being expressed by baculoviruses (Merryweather et al. 1990). Perhaps the most exciting aspect is the development of transgenic plants. The B.t. toxin gene was first transferred into tomato and tobacco plants in 1985 using the crown gall bacterium, Agrobacterium tumefaciens, as a natural gene transfer system (Vaeck et al. 1987). A B.t. toxin gene was recently transferred to a Populus sp. and tests conducted with forest tent caterpillar. Several Canadian research establishments are working on transformation in conifers.

The development of transgenic trees, expressing B.t. deltaendotoxin, is not without risk. There may be an unpredictable evolutionary response due to the complexity and longevity of the forest ecosystem (Raffa 1989). Pest species constantly exposed to B.t. toxins may develop resistance to them or non-pest species, unaffected by B.t. toxins, may fill the niche occupied by the pests of today and become the pest of tomorrow.

\section{Use of Viral Insecticides}

Field trials have been conducted on 19 species of forest insect pests in Canada, 11 Lepidoptera and 8 Hymenoptera (Table 2). Both aerial and ground trials have been conducted on 8 species; the remainder were tested with ground applications only. Three viral insecticides, all NPVs, were registered in Canada in 1983, two for the control of Douglasfir tussock moth, Orgyia pseudotsugata, and the third for redheaded pine sawfly, Neodiprion lecontei. Registration petitions were submitted in 1985 for an NPV to control European pine sawfly and in 1990 for an NPV to control gypsy moth (Table 2). 
Table 2. Viruses tested in Canada for control of lepidopterous and hymenopterous forest insect pests

\begin{tabular}{|c|c|c|c|c|}
\hline \multirow[b]{2}{*}{ Species } & \multicolumn{4}{|c|}{ Application } \\
\hline & Type of virus & Ground & Air & Registration status \\
\hline \multicolumn{5}{|l|}{ LEPIDOPTERA } \\
\hline $\begin{array}{l}\text { Spruce budworm } \\
\text { Choristoneura fumiferana }\end{array}$ & $\begin{array}{l}\text { NPV, GV } \\
\text { CPV, EPV }\end{array}$ & + & + & \\
\hline $\begin{array}{l}\text { Western spruce budworm } \\
\text { C. occidentalis }\end{array}$ & NPV, GV & + & + & \\
\hline $\begin{array}{l}\text { Jack pine budworm } \\
\text { C. pinus }\end{array}$ & NPV & & + & \\
\hline $\begin{array}{l}\text { Douglas-fir tussock moth } \\
\text { Orgyia pseudotsugata }\end{array}$ & NPV & + & + & $\begin{array}{l}\text { Virtuss \& TM BioControl-1 } \\
\text { registered } 1983\end{array}$ \\
\hline $\begin{array}{l}\text { Whitemarked tussock moth } \\
\text { O. leucostigma }\end{array}$ & NPV & + & + & \\
\hline $\begin{array}{l}\text { Gypsy moth } \\
\text { Lymantria dispar }\end{array}$ & NPV & & + & Disparvirus submitted 1990 \\
\hline $\begin{array}{l}\text { Forest tent caterpillar } \\
\text { Malacosoma disstria }\end{array}$ & NPV & + & + & \\
\hline $\begin{array}{l}\text { Bruce spanworm } \\
\text { Operophtera bruceata }\end{array}$ & NPV & + & & \\
\hline $\begin{array}{l}\text { Winter moth } \\
O \text {. brumata }\end{array}$ & NPV & + & & \\
\hline $\begin{array}{l}\text { Hemlock looper } \\
\text { Lambdina fiscellaria }\end{array}$ & NPV & + & & \\
\hline $\begin{array}{l}\text { Black army cutworm } \\
\text { Actebia fennica }\end{array}$ & NPV & + & & \\
\hline \multicolumn{5}{|l|}{ HYMENOPTERA } \\
\hline $\begin{array}{l}\text { European spruce sawfly } \\
\text { Diprion hercyniae }\end{array}$ & NPV & + & & \\
\hline $\begin{array}{l}\text { European pine sawfly } \\
\text { Neodiprion sertifer }\end{array}$ & NPV & + & + & Sertifervirus submitted 1985 \\
\hline $\begin{array}{l}\text { Redheaded pine sawfly } \\
N \text {. lecontei }\end{array}$ & NPV & + & + & Lecontvirus registered 1983 \\
\hline $\begin{array}{l}\text { Balsam fir sawfly } \\
N \text {. abietis complex }\end{array}$ & NPV & + & & \\
\hline $\begin{array}{l}\text { Swaine jack pine sawfly } \\
N \text {. swainei }\end{array}$ & NPV & + & + & \\
\hline $\begin{array}{l}\text { Red pine sawfly } \\
N . \text { nanulus nanulus }\end{array}$ & NPV & + & & \\
\hline $\begin{array}{l}\text { Jack pine sawfly } \\
\text { N. pratti banksianae }\end{array}$ & NPV & + & & \\
\hline $\begin{array}{l}\text { Red-headed jack pine sawfly } \\
N \text {. virginiana complex }\end{array}$ & NPV & + & & \\
\hline
\end{tabular}

Douglas-fir tussock moth is a sporadic pest in British Columbia. The last outbreak terminated in 1983 when two viral insecticides, Virtuss and TM BioControl-1, were registered. Neither product was used operationally until 1991 when 200 ha were treated. Virtuss is produced by the Forest Pest Management Institute and is propagated in whitemarked tussock moth larvae, Orgyia leucostigma. TM BioControl-1 is produced by the USDA Forest Service in Douglas-fir tussock moth larvae. It was registered in Canada to facilitate importation by the B.C. Forest Service, which in 1990 had sufficient TM BioControl-1 in storage to treat 8,000 ha and sufficient Virtuss to treat 1,400 ha. A pheromone-baited trapping program followed by egg mass surveys used to monitor Douglas-fir tussock moth populations (Shepherd and Otvos 1986). Virtuss is also effective against whitemarked tussock moth. It has been field tested in Newfoundland
(West et al., 1987; 1989) and this species may be added to the Virtuss label.

Lecontvirus for control of redheaded pine sawfly is the only viral insecticide which is used operationally on an annual basis. Prior to its registration in 1983, experimental aerial spray trials were conducted (Cunningham et al. 1986), but since 1983 applications have been from the ground. Redheaded pine sawfly is an important pest of red pine, Pinus resinosa, and jack pine, $P$. banksiana, plantations in Ontario and Quebec. Between 1976 and 1990, 590 plantations with a combined area of 4,900 ha have been treated with Lecontvirus supplied by the Forest Pest Management Institute.

European pine sawfly NPV was discovered in 1949 (Bird 1953 ) and extensively used in the 1950 s and 1960 s to control this major pest of ornamentals and Christmas tree plantations. This insect is currently only a minor pest due 
to use of virus and release of imported parasites. Between 1975 and 1990, 4 plantations with a combined area of 160 ha were treated experimentally. This virus is registered in the USA under the name Neochek-S and in the UK under the name Virox. American toxicology data were used to prepare a petition for a Canadian product called Sertifervirus. This registration petition was submitted to Agriculture Canada and is being evaluated.

Gypsy moth was not a major pest in Canada until 1981 when 1,000 ha of moderate-to-severe defoliation was reported around Kaladar, Ontario. Between 1982 and 1991, 37 plots, with a combined area of about 635 ha, have been treated with gypsy moth NPV products, either Gypchek, supplied by the USDA Forest Service, or Disparvirus, produced at the Forest Pest Management Institute. Research efforts intensified in 1988, with a view to recommending a dosage emitted volume and formulation that will enable this NPV to compete with B.t. which is widely used for gypsy moth control in Ontario. A registration petition for Disparvirus, based on the American Gypchek submission, was submitted to Agriculture Canada for evaluation in 1990. Gypsy moth NPV is a prime candidate for commercialization.

Since the inception of the Insect Pathology Laboratory, much effort has been expended on attempting to develop a viral insecticide for spruce budworm, which is North America's most important defoliating insect pest. Methods were developed to mass produce spruce budworm viruses in vivo in 1970 and a series of field trials was conducted between 1971 and 1983 when 65 plots with a total area of 2,656 ha were treated. Mainly NPV was applied, but a GV, CPV and EPV were also tested (Cunningham 1985b). The same viruses which infect spruce budworm also infect western spruce budworm and jack pine budworm. Between 1976 and 1982, 6 plots with a combined area of 424 ha were treated with NPV and GV to control western spruce budworm in British Columbia (Otvos et al. 1989) and one 50 ha plot in Ontario was treated with NPV to control jack pine budworm.

Extensive toxicology testing was undertaken with spruce budworm NPV in the 1970s, but results from research spray trials indicated that it did not merit registration. Virus epizootics have never been observed to terminate budworm outbreaks naturally and attempts to initiate epizootics have not been particularly successful. Budworm larvae are concealed until budflush when they have reached their fourth larval instar. If sprayed with virus at this stage, they are close to pupation when they die, no foliage is saved and there is no opportunity for horizontal transmission of the virus. The development of a successful viral insecticide for spruce budworm is a priority and genetic enhancement offers a pathway to this goal.

\section{Genetic Manipulation of Baculoviruses}

Several baculoviruses have been studied at the molecular level. Their genomes have been mapped, and some individual genes identified, cloned and sequenced. Alfalfa looper, Autographa californica, NPV is the most intensively studied baculovirus. The gene which codes for the inclusion body protein of baculoviruses is very strongly expressed. It can be deleted and replaced by an exogenous gene that is also strongly expressed (Smith et al. 1983). About 140 foreign genes have been inserted at this site by different research teams; most of these proteins have medical or veterinary applications. However, this technology can also be applied to the development of enhanced viral insecticides.

A possible method of improving the effectiveness of baculoviruses for insect pest control is to insert exogenous genes which encode for insect-specific toxins, hormones or other proteins that may disrupt insect metabolism (Kirshbaum 1985). The first environmental release of a genetically engineered baculovirus was in 1986 in the UK with alfalfa looper NPV containing a genetic marker (Bishop 1986). The B.t. toxin gene has been engineered into the same virus (Merryweather et al. 1990). There is great interest in determining which baculovirus genes influence host specificity and virulence so they can be manipulated. Several baculovirus genomes other than alfalfa looper NPV have been mapped and those infecting forest insect pests include spruce budworm NPV (Arif and Doerfler 1983, 1984), Douglas-fir tussock moth NPV (Leisy et al. 1984) and gypsy moth NPV (Smith et al. 1988).

\section{Conclusions}

There is widespread public opposition to the use of chemical pesticides in the forest and a growing demand for environmentally benign, host-specific, safe pest control agents. Many microbial insecticides fall into this category, but there is only one microbial insecticide, B.t., commercially available in Canada in sufficient quantities for widescale forestry use. Three viral insecticides are available, but their use is insignificant compared to use of B.t. Many of the factors that make microbial insecticides environmentally attractive deter commercialization. Highly specific pest control products have small markets compared to broad spectrum chemical insecticides, and development costs can be considerable.

A need exists for a new arsenal of products to replace the broad-spectrum chemical insecticides that were the mainstay of forest protection in the 1960s and 1970s. Research networking is a highly effective method of accelerating development of new products and processes. There are three networks in Canada involved in the development of microbial insecticides. Biocide was founded by the Forest Pest Management Institute in 1984. Members of Biocide are working on the development of improved B.t. products for forest insect pests generally, and spruce budworm in particular. Involved are the Institute, the National Research Council of Canada and two universities. A second network founded by the Forest Pest Management Institute in 1988, called Microbionet, encompasses mainly the genetic manipulation of insect viruses, although microsporidia may also be involved. There are 13 collaborators in four university departments and the National Research Council, as well as one industrial partner. A third network, Insect Biotech Canada, is centred at Queen's University, Kingston, Ontario. This network is funded by the Government of Canada under the Networks of Centres of Excellence Program and involves 24 scientists from 10 universities, one industrial partner and two government laboratories including the Forest Pest Management Institute. There are five main thrusts to this program, one being the molecular engineering of baculoviruses. 
Most industrial research is directed to development of new and improved B.t. products. Inexpensive production methods make B.t. a very attractive commodity. It is obviously an imprudent pest management strategy to rely entirely on one pest control agent and alternatives to B.t. are urgently required. Considerable research effort in Canadian government laboratories and universities is focused on viruses. They were long considered the panacea for forest insect control, but were overtaken by B.t. because of production problems and lack of commercial interest in viruses. Few companies want to produce entomopathogenic viruses in vivo, but if an economical method of producing them in cell culture is developed, many companies with expertise in vaccine production will likely take an interest in producing viral insecticides.

Viruses, however, are the first choice for control of certain pest species. Several sawfly viruses, including Lecontvirus and Sertifervirus, are more effective than chemical insecticides when applied on early instar larvae. Also, B.t. is ineffective against hymenopterous pests. Douglas-fir tussock moth populations collapse after several years due to naturally occurring virus epizootics, but not before tree mortality occurs. Spraying virus early in the outbreak cycle accelerates this collapse and it has been suggested that use of other agents may even prolong the infestation. There is considerable optimism that genetic engineering will produce more viral insecticides effective against spruce budworm and other major pests.

Nematodes may have considerably more potential in forestry than was previously thought. Nematodes can be used against a wide range of forest insect pests if the problem of desiccation has been resolved using an appropriate formulation and if they can be applied from the air. They can also be used in a more traditional way as soil drenches on nursery pests or treatment of seedlings prior to planting. Nematodes are commercially available from several companies in the USA, although the cost of large scale forestry applications of nematodes remains to be established.

Hopefully, development of a whole range of new microbial control products can be accelerated during the next decade brought about by networking and increased funding for research.

\section{References}

Angus, T.A. 1964. Canadian participation in insect pathology. Can. Entomol. 96: 231-241.

Arif, B.M. and W. Doerfler. 1983. Characterization of the DNA from Choristoneura fumiferana nuclear polyhedrosis virus. Zbl. Bakt. Hyg. Abt. Orig. A 254: 147-148.

Arif, B.M. and W. Doerfler. 1984. Identification and localization of reiterated sequences in the Choristoneura fumiferana MNPV genome. EMBO J. 3: 525-529.

Bird, F.T. 1953. The use of a virus disease in the biological control of the European pine sawfly, Neodiprion sertifer (Geoffr.). Can. Entomol. 85: 437-445.

Bishop, D.H.L. 1986. UK release of genetically marked virus. Nature 323: 496.

Carlton, B.C., C. Gawron-Burke and T.B. Johnson. 1990. Exploiting genetic diversity of Bacillus thuringiensis for the creation of new bioinsecticides. pp. 18-22 In Proc. Vth Int. Coll. Invertebr. Pathol. \& Microbial Control. Adelaide, Australia.

Cunningham, J.C. 1985a. Biorationals for control of spruce budworms. pp. 320-349 In Proc. CANUSA Spruce Budworms Research Symposium (C.J. Saunders, R.W. Stark, E.J.
Mullins and J. Murphy, Eds.). Bangor, Maine. 1984. Can. For. Serv., Ottawa.

Cunningham, J.C. 1985b. Status of viruses as biocontrol agents for spruce budworm. pp. 61-67 In Proc. Symp. Microbial Control of Spruce Budworms and Gypsy Moths (D.G. Grimble and F.B. Lewis, Coord.) Windsor Locks, Conn. 1984. USDA, For. Serv. Rept. GTR-NE-100.

Cunningham, J.C. and P.F. Entwistle. 1981. Control of sawflies by baculovirus. pp. 379-407 In Microbial control of pests and plant diseases 1970-1980 (H.D. Burges, Ed.). Academic Press, London.

Cunningham, J.C., P. de Groot and W.J. Kaupp. 1986. A review of aerial spray trials with Lecontvirus for control of redheaded pine sawfly, Neodiprion lecontei (Hymenoptera:Diprionidae), in Ontario. Proc. ent. Soc. Ont. 117: 65-72.

DeLucca, A.J., J.G. Simonson and A.D. Larson. 1981. Bacillus thuringiensis distribution in soils of the United States. Can. J. Microbiol. 7: 865-870.

Entwistle, P.F. and H.F. Evans. 1985. Viral control. pp. 347-412 In Comprehensive insect physiology, biochemistry and pharmacology (G.A. Kerkut and L.I. Gilbert, Eds.). Pergamon Press, Oxford, U.K.

Fast, P.G. and J. Régnière. 1984. Effect of exposure time to Bacillus thuringiensis on mortality and recovery of the spruce budworm (Lepidoptera:Tortricidae). Can. Entomol. 116: 123-130.

Fast, P.G., E.G. Kettela and C.J. Wiesner. 1986. Assessment of efficacy of Bacillus thuringiensis against the spruce budworm. New Brunswick Research and Productivity Council. Report No. C/86/005.

Gelernter, W.D. 1990. MVP ${ }^{\mathrm{TM}}$ Bioinsecticide: a bioengineered, bioencapsulated product for control of lepidopteran larvae. p. 14 In Proc. Vth Int. Coll. Invertebr. Pathol. \& Microbial Control. Adelaide, Australia.

Harvey, G.T. and J.M. Burke, 1974. Mortality of spruce budworm on white spruce caused by Entomophthora spaerosperma Fresenius. Environ. Can., For. Serv., Bi-monthly Res. Notes. 30: 23-24.

Heimpel, A.M. and T.A. Angus. 1959. The site of action of crystalliferous bacteria in Lepidoptera larvae. J. Insect Pathol. 1: $152-170$.

Kinghorn, J.M., R.A. Fisher, T.A. Angus and A.M. Heimpel. 1961. Aerial spray trials against the black headed budworm in British Columbia. Dept. For., Bimon. Prog. Rep. 17: 3-4.

Kirschbaum, J.B. 1985. Potential implications of genetic engineering and other biotechnologies to insect control. Annu. Rev. Entomol. 30: 51-70.

Lambert, M. 1987. Quantification of spray deposits in experimental and operational aerial spraying operations. pp. 125-129 In Proc. Symp. Aerial Application of Pesticides in Forestry. (G.W. Green, Ed). Assoc. Comm. Agric. Forestry Aviation, N.R.C., Ottawa. AFA-TN-18, NRC No. 29197.

Leisy, D.J., G.F. Rohrmann and G.S. Beaudreau. 1984. Conservation of genome organization in two multicapsid nuclear polyhedrosis viruses. J. Virol. 52: 699-702.

Martin, P.A.W. and R.S. Travers. 1989. Worldwide abundance and distribution of Bacillus thuringiensis isolates. Appl. Environ. Microbiol. 55: 2437-2442.

McGugan, B.M. and H.C. Coppel. 1962. Biological control of forest insects. 1910-1958, pp. 35-210 In A review of the biological control attempts against insects and weeds in Canada. Commonwealth Institute of Biological Control, Trinidad. Tech. Comm. No. 2.

Merryweather, A.T., V. Weyer, M.P.G. Harris, M. Hirst, T. Booth and R.D. Possee. 1990. Construction of genetically engineered baculovirus insecticides containing Bacillus thuringiensis subsp. kurstaki HD-73 delta endotoxin. J. gen. Virol. 71: 1535-1544. 
Mott, D.G., T.A. Angus, A.M. Heimpel and R.A. Fisher. 1961. Aerial application of Thuricide against spruce budworm in New Brunswick. Dept. For., Bimon. Prog. Rep. 17: 2.

Nambiar, P.T.C., S.-W. Ma and V.N. Iyer. 1990. Limiting an insect infestation of nitrogen-fixing root nodules of the pigeon pea (Cajanus cajan) by engineering the expression of an entomocidal gene in its root nodules. Appl. Environ. Microbiol. 56: 2866-2869.

Otvos, I.S. and B.H. Moody. 1978. The spruce budworm in Newfoundland: history, status and control. Can. For. Serv., St. John's, Nfld. Inf. Rep. N-X-150, 76 p.

Otvos, I.S., D. M. MacLeod and D. Tyrrell. 1973. Two species of Entomophthora pathogenic to eastern hemlock looper (Lepidoptera: Geometridae) in Newfoundland. Can. Entomol. 105: 1435-1441.

Otvos, I.S., J.C. Cunningham and W.J. Kaupp. 1989. Aerial application of two baculoviruses against the western spruce budworm, Choristoneura occidentalis Freeman (Lepidoptera:Tortricidae), in British Columbia. Can. Entomol. 121: 209-217.

Payne, C.C. 1986. Pathogenic viruses as pest control agents. pp. 183-200 In Biological plant and health protection (J.M. Franz, Ed.). C. Fischer Verlag, Stuttgart and New York.

Raffa, K.F. 1989. Genetic engineering of trees to enhance resistance to insects: evaluating the risks of biotype evolution and secondary pest outbreak. Bioscience 39: 524-534.

Shepherd, R.F. and I.S. Otvos. 1986. Pest mangement of Douglas-fir tussock moth: procedures for insect monitoring, problem evaluation and control actions. Can. For. Serv., Pac. For. Res. Cen., Victoria, B.C. Inf. Rep. BC-X-270. 14 p.

Smirnoff, W.A. and O.N. Morris. 1982. Field development of Bacillus thuringiensis in eastern Canada. pp. 238-247 In Biological control programmes against insects and weeds in
Canada 1969-1980 (J.S. Kelleher and M.A. Hulme, Eds.). Commonwealth Agricultural Bureaux, Slough, U.K.

Smith, G.E., M.D. Summers and M.J. Fraser. 1983. Production of human beta-interferon in insect cells with a baculovirus expression vector. Mol. Cell. Biol. 3: 2156-2165.

Smith, I.R.L., N.A.M. van Beek, J.D. Podgwaite and H.A. Wood. 1988. Physical map and polyhedrin gene sequence of Lymantria dispar nuclear polyhedrosis virus. Gene 71: 97-105.

Vaeck, M., A. Reynaerts, H. Höfte, S. Jansens, M. De Beuckeleer, C. Dean, M. Zabeau, M. van Montagu and J. Leemans. 1987. Transgenic plants protected from insect attack. Nature 328: 33-37.

van Frankenhuyzen, K. 1990. Development and current status of Bacillus thuringiensis for control of defoliating insects. For. Chron. 66: 498-507.

van Frankenhuyzen, K. and C.W. Nystrom. 1987. Effect of temperature on mobility and recovery of spruce budworm (Lepidoptera:Tortricidae) exposed to Bacillus thuringiensis Berliner. Can. Entomol. 119: 941-954.

West, R.J., J.C. Cunningham and W.J. Kaupp. 1987. Ground spray applications of Virtuss ${ }^{\mathrm{R}}$, a nuclear polyhedrosis virus, against whitemarked tussock moth larvae at Bottom Brook, Newfoundland in 1986. Can. For. Serv., Nfld. For. Res. Cen., St. John's, Nfld. Inf. Rep. N-X-257. 10 p.

West, R.J., W.J. Kaupp and J.C. Cunningham. 1989. Aerial application of Virtuss ${ }^{\mathrm{R}}$, nuclear polyhedrosis virus, against whitemarked tussock moth in Newfoundland in 1987. For. Can., Nfld. and Lab. Region, St. John's, Nfld. Inf. Rep. N-X-270, 10 p.

Wilson, G.G. 1982. Protozoans for insect control. pp. 587-600 In Microbial and viral pesticides (E. Kurstak, Ed.). Marcel Dekker, N.Y. 